\title{
Proposal of a methodology for pre-selection of sewage treatment systems within watersheds
}

\section{Proposta metodológica para pré-seleção de sistemas de tratamento de esgoto no âmbito de bacias hidrográficas}

\author{
Lucas Luiz Dall’Orto Fantin ${ }^{1}$, José Antonio Tosta dos Reis ${ }^{1}$ and Antonio Sérgio Ferreira Mendonça ${ }^{1}$ \\ ${ }^{1}$ Universidade Federal do Espírito Santo, Vitória, ES, Brazil \\ E-mails: lucas.fantin@hotmail.com (LLDOF),jatreis@gmail.com (JATR), anserfm@terra.com.br (ASFM)
}

Received: June 14, 2016 - Revised: October 19, 2016 - Accepted: October 19, 2016

\begin{abstract}
The selection of sewage treatment plants within watersheds is a complex process when there are multiple outflows presenting different loads and watercourses presenting different assimilation capabilities. In this context, the present study aims to establish a methodology for pre-selection of wastewater treatment alternatives within watersheds. The methodology involves the combined use of water quality model, optimization technique and a set of technical and economic criteria associated with different wastewater treatment systems. To evaluate the proposed methodology there were considered different effluent disposal scenarios in the Pardo river watershed. Pardo is a major tributary of the Itapemirim river, watercourse located in the southern portion of Espírito Santo State, Brazil. The results indicated that the optimization model, that aimed to minimize wastewater treatment efficiencies within the watershed, considering watercourses self-purification capacities, selected treatment systems ranging from the combination of UASB and polishing lagoons systems to slow infiltration, treatment alternatives that presented the lowest net cost estimates. The incorporation of equity perspective between treatment systems increased the total present net cost associated with wastewater treatment within the watershed.
\end{abstract}

Keywords: Water quality model; Optimization; Genetic algorithm; Wastewater treatment.

\section{RESUMO}

O processo de seleção de uma estação de tratamento de esgoto é complexo quando observado do ponto de vista de uma bacia hidrográfica, onde existem múltiplos lançamentos apresentando diferentes cargas e corpos d'água com diferentes capacidades de assimilação. Neste contexto, a presente pesquisa tem como objetivo estabelecer metodologia para a pré-seleção de alternativas de tratamento de esgoto no âmbito de bacias hidrográficas. A proposta metodológica envolve o uso combinado de modelo de qualidade de água, técnica de otimização e um conjunto de critérios de natureza técnica e econômica associados aos diferentes sistemas de tratamento de esgotos. Para avaliação da metodologia proposta foram considerados diferentes cenários de disposição de efluentes na bacia hidrográfica do rio Pardo, importante afluente do rio Itapemirim, curso d'água da porção sul do estado do Espírito Santo. Os resultados indicaram que o modelo de otimização que buscou a minimização das eficiências de tratamento no âmbito da bacia, permitindo uso da capacidade e de autodepuração dos cursos d'água, selecionou sistemas de tratamento que variaram da combinação de reatores UASB e lagoas de polimento a sistemas de infiltração lenta, alternativas de tratamento que apresentaram menores estimativas de custos presentes líquidos. A incorporação da equidade entre os sistemas de tratamento aumentou significativamente os custos presentes líquidos totais associados ao tratamento de esgoto no âmbito da bacia hidrográfica.

Palavras-chave: Modelo de qualidade de água; Otimização; Algoritmo genético; Tratamento de esgotos. 


\section{INTRODUCTION}

Urban areas population concentration is one of the main aspects to be considered in water resources management. Densely occupied regions usually present high water demands, both for public and industrial supply, as well as for dilution and removal of pollutant loads. In Brazil, increasing urban and industrial pollution loads, associated with inadequate land use, erosion, deforestation, indiscriminate use of agricultural inputs and mining have made water supply and water quality conditions severe in many places. Among water quality control measures, individual or collective sewage treatment before final disposal is usually the main - and often the only - control strategy through which it is sought released pollutants concentrations reduction to enable compliance with the watercourses quality standards recommended by Brazilian environmental legislation (VON SPERLING, 2005).

The sewage treatment system selection process should be based on the analysis of technical, economic and environmental criteria, taking into account treatment alternatives qualitative and quantitative aspects (VON SPERLING, 2005). Cost, however, is usually considered the most relevant aspect for the selection of treatment plants (TCHOBANOGLOUS; BURTON, 1991).

The sewage treatment plant selection problem becomes more complex when observed from point of view of a river watershed, where there are multiple releases presenting different loads and water bodies presenting different quality conditions and assimilation capacities (REIS; VALORY; MENDONÇA, 2015).

In this context, the use of water quality simulation models can support sewage treatment systems selection processes. Park and Lee (2002), Paliwal, Sharma and Kansal (2007), Zhu et al. (2008), Zhang et al. (2012), Salla et al. (2013) and Calmon et al. (2016) works, for example, illustrate how water quality mathematical models can support the evaluation of raw or treated effluents final disposal effects on surface watercourses. However, water quality mathematical simulation alone does not indicate the optimal solutions for sewage treatment systems definition problems. Through integration of water quality models and optimization techniques it is possible to achieve the optimal combination of treatment systems to be adopted within a basin when systems definition involves multiple objectives (ANDRADE; MAURI; MENDONÇA, 2013).

According to Cho, Seok Sung and Ryong Ha (2004) and Aras, Togan and Berkun (2007), mathematical programming conventional methods (Linear Programming, Nonlinear Programming, Dynamic Programming) have been used repeatedly to solve problems associated with the selection of sewage treatment systems. In addition, these authors note that, due to the limitations of conventional methods and the rapid development of computers and software, new optimization methods such as Genetic Algorithm, Fuzzy Logic and Artificial Neural Networks have been progressively more employed for solving sewage treatment plants selection problems.

The Genetic Algorithm, a search algorithm that seeks to solve optimization problems, based on the Evolution of Species Theory (theory originally established by the English physiologist Charles Darwin), has as basic foundation that the evolution of individuals (solutions of the optimization problem) occurs by stochastic in nature genetic operators application. These search strategies for the best optimization problems solutions have been efficient, usually leading to the global optimal value (NICKLOW; KAINI; ARTITA, 2012).

Burn and Yulianti (2001), Aras, Togan and Berkun (2007), Nicklow, Kaini and Artita (2012), Cho and Lee (2014) and Valory, Reis and Mendonça (2015) works employed water quality models and Genetic Algorithm for selecting sewage treatment systems within watersheds. The optimization models proposed by these authors, structured from the combination of different functions and objectives, were established with the incorporation of aspects such as implementation and treatment costs minimization, loads maximization, numbers of environmental quality standards violations and/or violations magnitudes minimization.

The main objective of this work is to establish a methodological proposal for pre-selection of sewage treatment processes within a river basin. The proposal involves the combined use of water quality model and Genetic Algorithm, similar to the works conducted by the authors indicated in the previous paragraph. However, it covers technical criteria and incorporates economic analysis associated with operation and implementation costs for different sewage treatment options. The proposed methodology, even intended to be generic for application in any river basin, will be applied in this study considering different sanitary effluent disposal conditions in the Pardo river basin. This river is located in the Espírito Santo State, in Brazil.

\section{STUDY AREA}

The study area considered in this study is the Pardo river catchment area, an important tributary of the Itapemirim river. This river is the main watercourse in the southern portion of the Espírito Santo State. The Pardo river basin drainage area, maximum altitude and perimeter are approximately $611 \mathrm{Km}^{2}, 1,580 \mathrm{~m}$ and $114 \mathrm{~km}$, respectively.

The region economy relies heavily on marble and granite extraction and processing. There are also alcoholic beverage industries and agricultural production, as well as slaughterhouses and dairy cooperatives. Existing and potential conflicts are concentrated on the need to preserve rivers water quality in order to obtain potable water by treatment, considering the existence of these potentially polluting activities (IEMA, 2015).

Pardo river basin (Figure 1) includes Pardo river and three main tributaries (Ribeirão São José, Pardinho and Ribeirão Perdição rivers). The Pardo river receives domestic sewage outflows from Ibatiba and Iúna municipalities. The Pardinho river, in turn, receives domestic sewage outflows from Irupi municipality. Perdição river receives domestic sewage produced by Santíssima Trindade and Nossa Senhora das Graças villages, settlements located in Iúna municipality rural area. There is no sewage treatment plant installed in any of the domestic waste disposal points.

Figure 2 shows, schematically, the modeled water system, indicating the main watercourses, their extensions by segments (from segment 1 to 8 ) and the different raw domestic sewage outflow points associated with the Pardo river basin. Pardo river total extension under analysis corresponds to $57.9 \mathrm{~km}$.

For Rio Pardo and tributaries water quality modeling, there were used information gathered by Calmon et al. (2016), when evaluating the use of quality permanence curves to support 


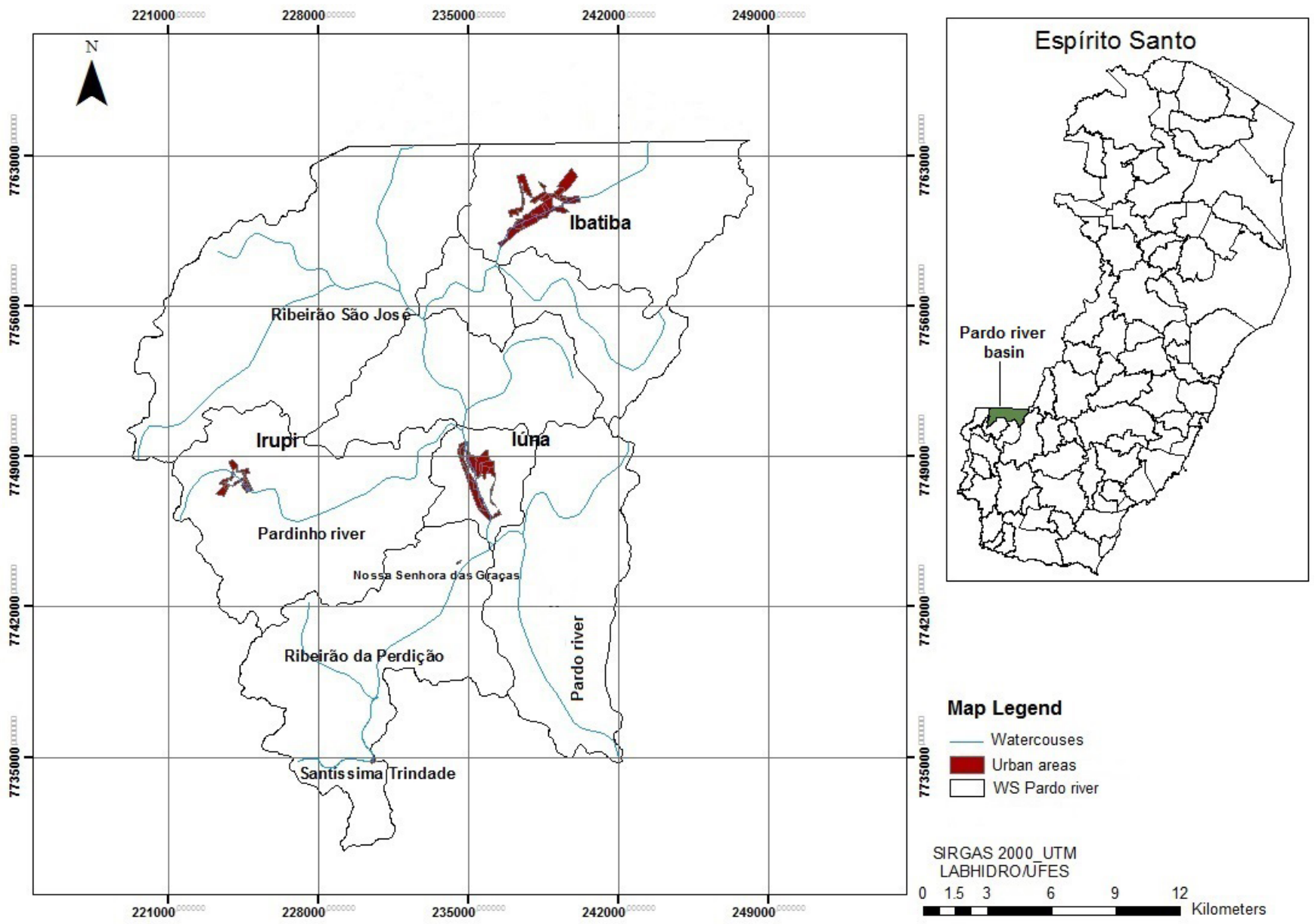

Figure 1. Pardo river basin water system.

\section{Tributary ribeirão São José}

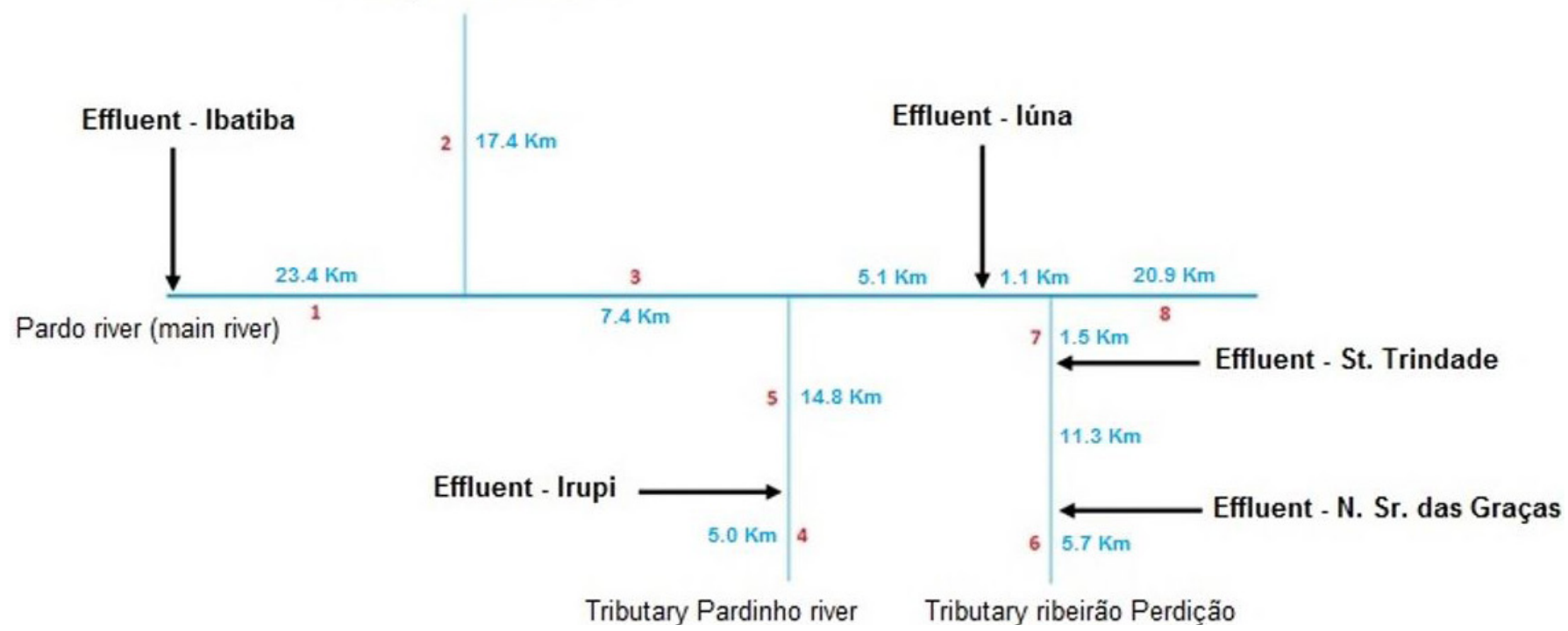

Figure 2. Pardo river basin single-line diagram. 
water quality classes uses definition for the same rivers. From these authors, information was obtained concerning Pardo River and its main tributaries minimum reference flows and quality conditions, effluent flows produced by the different population nuclei, expressions used for kinetic constants appropriation and expressions used for relations between flow variables, velocities and depths watercourses mean variables and other expressions necessary for the water quality model application.

\section{MATERIALS AND METHODS}

\section{Water quality modeling}

For water quality simulation, the computational model developed by Valory (2013) was utilized. This model reproduces, in a MatLab software environment, the mathematical functions used by QUAL-UFMG model to simulate DO spatial variation and BOD concentrations. In Brazil, the use of the QUAL-UFMG model - which has its functional and computational representations detailed by Von Sperling (2007) - has become frequent, as shown by Teodoro et al. (2013), Salla et al. (2013), Von Sperling and Von Sperling (2013) and Calmon et al. (2016). In the simulated sections, the mass balance was made by considering the contribution of point and distributed sources. Point sources were constituted by Pardo river tributaries (Pardinho, Perdição and São José rivers) and the five domestic effluents outflows from the urban nuclei located in the Pardo river basin (Ibatiba, Iúna, and Santíssima Trindade and Nossa Senhora das Graças districts). The distributed sources, in turn, were composed by incremental flows and BOD loads associated with rural population sewage.

Calmon et al. (2016) estimated the incremental flow for watercourses located in the Pardo river basin by means of mass balance, considering the difference between the flows in the final section of the simulated reaches and the flow in their headwaters. For simulations, carried out in the Pardo river basin, the incremental flow rate $3.53 \mathrm{~L} / \mathrm{s}$ was assumed, presenting $5 \mathrm{mg} / \mathrm{L}$ and $2 \mathrm{mg} / \mathrm{L}$ DO and BOD concentrations, respectively. These $\mathrm{DO}$ and BOD concentration values were assumed according to Von Sperling (2007).

Pardo river basin watercourses flows, domestic sewage flows, depths, temperatures and kinetic coefficients were those adopted by Calmon et al. (2016).

For flow values, $50 \%$ of the reference flows used in the granting process in the State of Espírito Santo $\left(Q_{00}\right)$ were considered. All flow values were estimated from flow measurements performed at the Terra Corrida - Montante station, a flow gauging station installed and operated by the Brazilian National Water Agency (ANA).

Calmon et al. (2016) indicated a $20.6{ }^{\circ} \mathrm{C}$ average temperature and an 846 meters average altitude for the Pardo river basin. This information supported water body oxygen saturation concentration. determination. In this work, $8.11 \mathrm{mg} / \mathrm{L}$ saturation concentration was assumed considering value estimated by using expression proposed by Popel (1979).

The functional relations between flow and velocity and between flow and depth (potential functions in the QUAL-UFMG model) were established from records of flow measurements performed at the Terra Corrida - Montante flow gauging station, operated in the Pardo river. Equations 1 and 2, also appropriated from Calmon et al. (2016), allowed estimates of watercourses velocities and depths as a function of flow rates.

$$
\begin{aligned}
& U=0.1433 \times Q^{0.6305} \\
& H=0.6076 \times Q^{0.2566}
\end{aligned}
$$

In Equations 1 and 2, $\mathrm{U}$ represents the mean velocity $(\mathrm{m} / \mathrm{s}), \mathrm{H}$ the mean depth $(\mathrm{m})$ and $\mathrm{Q}$ the flow $\left(\mathrm{m}^{3} / \mathrm{s}\right)$.

The average domestic sewage flows values relative to Pardo river basin urban populations are presented in Table 1.

Considering EPA (1985) and Thomann and Mueller (1987), BOD oxidation coefficient in watercourses $\left(\mathrm{K}_{\mathrm{d}}\right)$ was assumed to be $0.5 \mathrm{~d}^{-1}$, a conservative value in terms of organic loads reduction in the receiving bodies, consistent with current technical literature typical values.

The kinetic constant that regulates the atmospheric redox process $\left(\mathrm{K}_{2}\right)$ was estimated by the original expression defined by O'Connor and Dobbins, in 1958, considering relations between flows and speeds (Equation 1) and flows and depths (Equation 2). Equation 3 defines the kinetic constant that regulates the atmospheric re-reaction process.

$$
K_{2}=3.73 \times\left(0.1433 \times Q^{0.63}\right)^{0.5} \times\left(0.6076 \times Q^{0.26}\right)^{-1.5}
$$

According to Von Sperling (2007), processes involving algal interrelations with other constituents are quite complex and coefficients are not easily determined. In addition, interactions with algae present are more important for lentic environments. Therefore, for DO profiles simulation, the DO production (Photosynthesis) and consumption (Breathing) rates associated with algal biomass were disregarded in the present study.

The inversion of the bottom sludge layer, which is not normally fully stabilized, can be considered a source of BOD, compensating its decay due to the sedimentation processes. Thus, BOD decay coefficients related with sedimentation and oxygen demand associated with sediments were not considered. This disregard of the organic matter sedimentation phenomenon is in favor of safety, considering final disposal of raw sewage, since in BOD modeling it is not considered the BOD decrease resulting from sedimentation. Additionally, it is important to observe that the amount of sedimentable solids present in the final treated sewage effluent is usually very low, with less influence

Table 1. Domestic sewage average flows and urban populations in the Pardo river basin for the analysis time horizon.

\begin{tabular}{lcc}
\hline Urban nucleus & $\begin{array}{c}\text { Urban population } \\
\text { (in habitants) }\end{array}$ & $\begin{array}{c}\text { Urban outflow } \\
\text { (L/s) }\end{array}$ \\
\hline Ibatiba & 18125 & 24.33 \\
Irupi & 4918 & 5.24 \\
Iúna & 14821 & 19.90 \\
N. Sa das Graças & 600 & 0.64 \\
St $^{2}$. Trindade & 301 & 0.32 \\
\hline
\end{tabular}


of sedimentation and possibility of formation of bottom sludge in the water body (VON SPERLING, 2007).

The raw domestic sewage $\mathrm{BOD}_{5,20}$ concentration adopted was $400 \mathrm{mg} / \mathrm{L}$. This value corresponds to an upper limit for this kind of effluent, as indicated by Von Sperling (2005) and Jordão and Pessoa (2005). DO concentration for the raw domestic sewage was assumed to be null. It is important to note that the zero value assumed for the raw and, consequently, treated sewage DO concentration was adopted in order to simulate more rigorous scenarios than some of those that happen in practice, since some treatment plants generate effluent releases presenting DO concentrations that can reach $2 \mathrm{mg} / \mathrm{L}$, as in activated sludge processes cases.

In the present study, due to the lack of consistent information about sanitary sewage in the Pardo river basin rural areas, it was assumed, in safety favor, that any BOD load from the sewage generated by the rural population would reach the water bodies with no reduction caused by individual systems treatments or soil raw sewage disposal, generating direct incremental BOD loads throughout all the Pardo and Pardinho rivers and Perdição and São José creeks extensions. The adopted BOD incremental load was $9.35 \mathrm{~g} \mathrm{DBO/day.m,} \mathrm{as} \mathrm{assumed} \mathrm{by} \mathrm{Calmon} \mathrm{et} \mathrm{al.} \mathrm{(2016).}$

\section{Optimization technique}

The optimization technique employed in the present study is the Genetic Algorithm (GA), a direct search optimization stochastic population method inspired by the mechanisms of evolution of the species, which comprise population genetics processes and individuals survival and adaptation. The works of Holland (1975), Holland and Goldberg (1989), Michalewicz (1994) and Lacerda and Carvalho (1999) discuss the different conceptual aspects associated with GA use.

Water quality model and GA were jointly used to determine the minimum treatment efficiencies associated with each effluent disposal point, that is a primary information for pre-selection of sewage treatment systems. This determination precedes the consideration of other technical and economic criteria.

The GA operators and parameter values employed in the optimization procedure reproduced those used by Valory (2013), when assessing sewage treatment efficiencies for hypothetical effluent releases in Santa Maria da Vitória river basin upper portion, also located in Espírito Santo State, Brazil. In this way, the following operators and corresponding parameters were assumed:

- Initial population presenting 20 (twenty) individuals, sufficient for convergence to solve the optimization problem without relevant demands regarding processing times;

- The selection was applied to create an intermediate population, submitted to the crossing and mutation processes to define the next generation. Tournament selection was used and 10 (ten) individuals from the initial population were randomly selected to participate in the process;

- The individual who presented the highest fitness was chosen to compose the intermediate population;
- From the intermediate population, the selected individuals were crossed with each other, and then the mutation operators were applied. For the crossover, a 50\% rate was assumed;

- For the mutation - operator whose purpose is to ensure the diversity of individuals - it was adopted an adaptive mutation, a type that randomly generates mutations in the genes so that individuals adhere to the objective function and established restrictions;

- Elitism was used to preserve and refer the most adapted individual from each generation to the next generation. This individual was not modified by the different genetic operators employed in this study.

The GA is a Metaheuristic optimization technique. Its application, therefore, does not guarantee the achievement of global optimum. Genetic Algorithms, while not necessarily providing the overall optimal solution, are capable of providing reasonable solutions with processing time considered feasible. In order to alleviate the problem of failure to obtain the global optimum, five (5) simulations were conducted for each employed optimization model. The appropriation of equal or close solutions indicated that the global optimum was obtained or approached.

\section{Optimization models}

In this work, the main objective of optimization models application is to minimize the sum of treatment efficiencies or inequity between different sewage treatment plants associated to the Pardo river basin, imposing as restrictions the maintenance of quality standards required by CONAMA Resolution Number 357/2005 (BRASIL, 2005) for all water bodies reaches analyzed. Different optimization models for sewage treatment systems in river basins selection processes can be found in Mulligan (1991), Marsh and Schilling (1994), Burn and Yulianti (2001), Reis, Valory and Mendonça (2015) and Santoro (2016) works.

Equation 4 and Inequalities from 5 to 8 form the first optimization model (optimization model 1), assuming Pardo river basin watercourses as class 2 . It is important to note that the Pardo river and its tributaries have not undergone water uses classes definition. In this context, the water quality standards indicated for DO and BOD in class 2 rivers have shaped the constraints established by Inequalities 7 and 8 .

$$
\begin{aligned}
& \text { Minimize }[f(E)]=\sum_{i=1}^{n} E_{i} \\
& \text { Ei }(\text { Efficiency }) \geq 0 \\
& \text { Ei }(\text { Efficiency }) \leq 90
\end{aligned}
$$

Watercourse $B O D \leq 5.0$

Watercourse $D O \geq 5.0$ 
The second optimization model (optimization model 2), originally proposed by Burn and Yulianti (2001), presents the objective function equation (9). This model presents as main objective the determination of treatment efficiencies in a context of inequality between systems minimization. The Inequalities 5 to 8 also represent optimization model 2 constraints.

Minimize $f(E)=\sum_{i=1}^{n}\left|\left(\frac{\operatorname{Load}_{\text {Raw sewage (i) }}}{E_{(i)}}\right)-\left(\frac{\overline{\overline{\text { Load }_{\text {Raw sewage }}}}}{\bar{E}}\right)\right|$

In Equations 4 and 9 and in inequalities from 5 to 8, Ei represents $i^{\text {th }}$ sewage treatment system BOD removal efficiency considered for the basin, Watercourse BOD the Biochemical Oxygen Demand value for the treated sewage and Watercourse DO the Dissolved Oxygen concentration in the watercourse.

In Equation 9, the relationship established by Load Discharge $_{i}$ (raw sewage organic load from the $\mathrm{i}^{- \text {th }}$ effluent discharge in the basin) and $\mathrm{Ei}$ (BOD removal efficiency from the $i^{\text {th }}$ treatment system in the water system) represents equity among different considered outflows. Thus, the greater the raw organic load associated with a particular outflow, the greater the estimated BOD removal efficiency at that effluent discharge point.

According to CONAMA Resolution Number 430/2011, Article 21, the maximum permitted treated effluents BOD concentration is $120 \mathrm{mg} / \mathrm{L}$. However, the same Resolution indicates that such concentration may be exceeded in those situations where the treatment system presents a minimum BOD removal efficiency $60 \%$ or when the receiving body self-purification capacity is sufficient to keep DO and BOD concentrations inside limits corresponding to the watercourses water use classes objectives (BRASIL, 2011). In this context, an additional constraint associated to the BOD removal was added to the optimization model 1, establishing three different optimization groups for each of the effluent disposal scenarios object of simulation. Additional restrictions admitted the following forms:

- $\quad \mathrm{Ei} \geq 0$ : raw sewage is admitted, considering that all organic matter will be assimilated by the watercourses self-purification capacities, with the BOD values within the limits established by CONAMA Resolution 357 for all water systems;

- Treated BOD $\leq 120 \mathrm{mg} / \mathrm{L}$ : observing the maximum BOD value in treated sewage, as established by CONAMA Resolution 430/2011;

- $\quad$ Ei $\geq 60 \%$ : According to the minimum BOD removal efficiency value established by CONAMA Resolution $430 / 2011$, it is accepted the release of treated sewage presenting BOD concentration values higher than $120 \mathrm{mg} / \mathrm{L}$.

\section{Technical criteria and costs for the implementation and operation of sewage treatment systems}

The different technical criteria and implementation and operation costs associated to different sewage treatment systems, necessary for the pre-selection process, were obtained from Von Sperling (2005), Jordão and Pessoa (2005) and USP (2004) works.

\section{Economic analysis}

For economic analysis, it was employed the Net Present Value Method (NPV), which consists of determining a value at an instant considered as initial, from a cash flow formed by a series of revenues and expenditures (HIRSCHFELD, 2012).

Considering the existence of cash flow benefits and costs, the sum of all benefits (positive) and costs (negative) values produces the cash flow net present value. Thus, if the net cash flow present value is positive, there is predominance of the present benefits values in relation to the costs. On the other hand, if the net cash flow presents negative value, there is predominance of costs present values in relation to the benefits, both obtained with the application of a characteristic interest rate. Equation 10 shows that a given alternative net present cash flow value is therefore the algebraic sum of the various present values involved.

$$
N P L=\sum F_{n}(1+i)^{-n}
$$

In Equation 10:

- NPL: net cash flow present value for a given alternative;

- $n$ : number of periods involved in each element of the revenues and cash flow expenditures series;

- $\mathrm{F}_{\mathrm{n}}$ : each of the various amounts involved in the cash flow;

- i: comparative interest rate or minimum attractiveness rate, also known as the equivalence, expectation or discount rate.

When there is expenditures predominance, or for cases where they make up the entire cash flow, it is made signals conversion, meaning that the benefits become negative and the costs positive. In order to avoid confusion, the net present cost (CPL) is presented as the net present value with negative sign:

$$
C P L=-N P L
$$

In this work, a 5\% discount rate (i) and a 20 year period sewage treatment systems useful life were considered for the CPL calculation. As the present work covers the pre-selection of sewage treatment systems, the economic analysis objective is to indicate the alternative that would offer the lowest cost. In this context, the CPL of all the sewage treatment options are calculated and those that present the lowest net present cost values are chosen as the best treatment alternatives, for each effluent disposal point.

\section{Sewage treatment systems pre-selection for the Pardo river basin}

A computer program was developed, in a MatLab software environment, to carry out the pre-selection of feasible sewage treatment systems based on technical and economic criteria analysis. Regarding the economic analysis, the program appropriates the costs associated with treatment systems implementation, operation and maintenance, among those that have met efficiency requirements and other technical criteria selected for analysis. In addition, it appropriates the CPL values for viable sewage treatment alternatives 
according to the interest rate and the estimated useful life. At the end of the process, sewage treatment systems are ordered considering increasing CPL values.

In order to demonstrate the application of the procedure for treatment systems pre-selection, different hypothetical scenarios were considered, based on different technical criteria combinations.

Although the best understanding of the study area could lead to a more consistent selection of technical criteria to be met at the different disposal points for the villages located in the rural area of Iúna municipality (Santíssima Trindade and Nossa Senhora das Graças villages) there were prioritized non-mechanized systems, associated with low energy consumption. In this way, different scenarios were defined as follows:

- Scenario 1: only the minimum treatment efficiencies were considered, not requiring attendance of any other technical nature condition;

- Scenario 2: no mechanized systems were allowed in any of the effluent disposal points, in order to limit the energy consumption. In this case, only systems that do not require power for operation could be chosen in the pre-selection process. In addition, soil treatment and final disposal systems were not allowed;

- Scenario 3: Only in the Santíssima Trindade and Nossa Senhora das Graças villages treatment systems that require electric energy for operation were not admitted. In these localities, soil treatment and final disposal systems were accepted, an alternative not considered for the Ibatiba, Iúna and Irupi municipal nucleus.

In the different simulation scenarios setup, three different sewage treatment conditions were considered, according to additional restrictions indicated in the "Optimization Models" section: a) Condition 1: raw sewage disposal, considering that all organic matter would be assimilated by the watercourses self-purification capacities, ensuring the maintenance of the DO and BOD concentrations within class 2 limits, as established by the CONAMA Resolution 357/2005, in all watercourses reaches; b) Condition 2: maximum $120 \mathrm{mg} / \mathrm{L}$ BOD values for treated sewage outflows, according to CONAMA Resolution 430/2011; and c) Condition 3: imposition of BOD removal treatment efficiency greater than or equal to $60 \%$, in accordance with CONAMA Resolution 430/2011, admitting treated sewage BOD concentration values higher than $120 \mathrm{mg} / \mathrm{L}$.

It is important to note that the use of optimization model 2 aims to evaluate the variation of efficiencies with treatment systems equity perspective introduction. Considering this aspect, the optimization model 2 was only used for final effluents disposal Condition 1.

\section{RESULTS AND DISCUSSION}

\section{Water quality modeling considering final disposal of raw effluents}

A first simulation conducted with the help of the water quality model considered the disposal of raw domestic sewage in five disposal points. This simulation allowed the evaluation of Pardo river basin watercourses dilution and self-purification capacities through the analysis of $\mathrm{DO}$ and BOD concentration profiles. Figure 3 shows the DO and BOD concentration profiles along the entire Pardo river simulated extension, considering different inflows produced by tributaries and raw domestic effluents. In this figure (and in the others that are presented in this section) the red lines refer to the quality standards for class 2 rivers uses, according to CONAMA Resolution 357/2005.

BOD concentration peaks are associated to the effluent inputs produced by Ibatiba (beginning of the simulated section), Irupi $(\mathrm{km} \mathrm{14.5)}$ and Iúna ( $\mathrm{km} \mathrm{19.6)} \mathrm{municipalities.} \mathrm{The} \mathrm{highest}$ BOD concentration estimated with quality model aid resulted from Ibatiba (most populous municipality located in the basin) municipality effluents disposal, approximately $18.8 \mathrm{mg} / \mathrm{L}$. In the stretch between Ibatiba municipality and the confluence with the São José stream ( $\mathrm{km} \mathrm{7.1)}$ the BOD concentration slightly decreased to values little higher than $10.0 \mathrm{mg} / \mathrm{L}$. The São José stream, which does not receive domestic sewage inputs, produced a significant dilution of the domestic sewage produced by Ibatiba population. It is important to note that the effluents produced by Irupi municipality (located in the Pardinho river basin), one of the three municipalities that most contribute to BOD load generation in the Pardo river watershed, did not produce significant increase in the Pardo river BOD concentration. This is due to the fact that, along the Pardinho river, the effluent BOD concentration
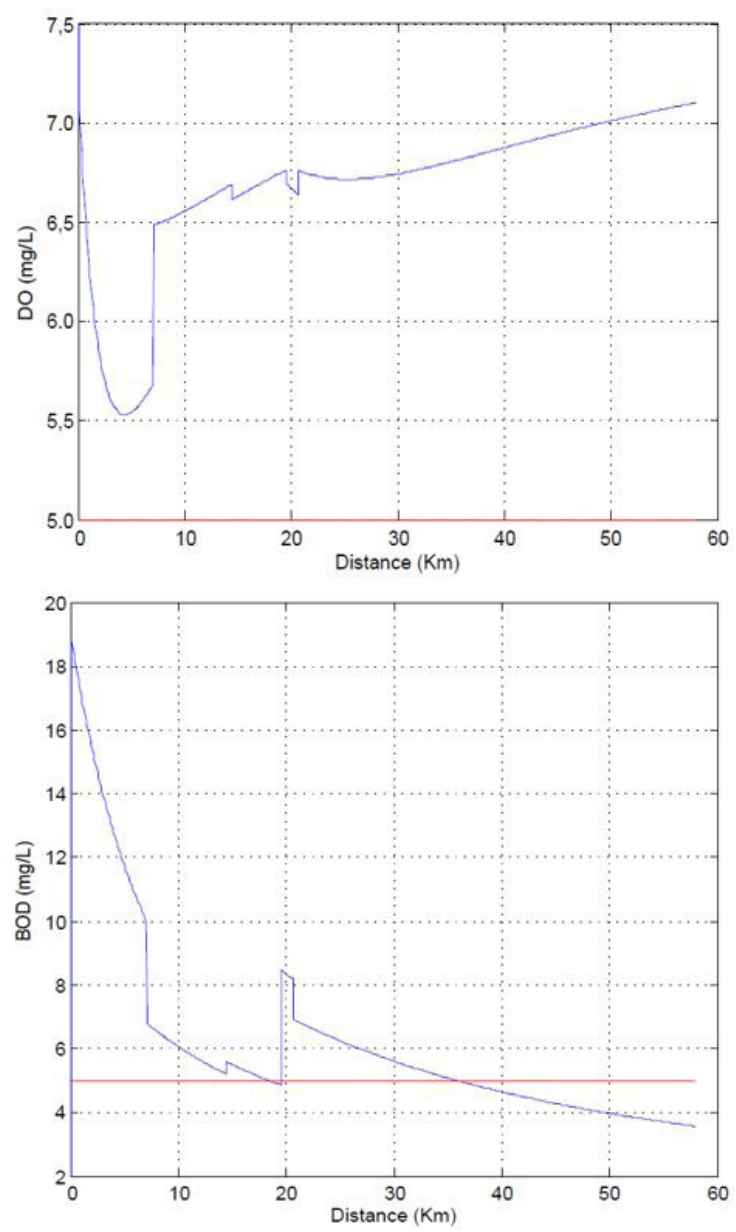

Figure 3. DO and BOD profiles along the Pardo River. 
produced by Irupi municipality was substantially reduced by the self-purification process.

The second highest concentration peak estimated by the water quality model $(8.5 \mathrm{mg} / \mathrm{L})$ was due to the final disposal of the sewage produced by Iúna municipality, the second most populous municipality located in the basin. The raw sewage load associated with the Iúna municipality presented a small decay up to kilometer 20.7, where tributary Ribeirão Perdição discharge the occurs. This watercourse, even receiving sewage from Iúna villages (Santíssima Trindade and Nossa Senhora das Graças), contributes to the dilution of the Iúna municipality effluents. It is important to note that, with the help of the water quality model, it was possible to observe that the BOD concentrations along the Pardo river would remain above the corresponding environmental quality standard for class 2 rivers uses, if established the boundary conditions that conform the simulations.

The DO concentration reductions along the Pardo river are related to the $\mathrm{BOD}$ concentration peaks, since the oxidation of organic matter in the raw sewage requires DO for decomposing microorganisms, mainly composed by aerobic heterotrophic bacteria, respiration maintenance.

Due to the discharge of the raw sewage generated in the Ibatiba municipality, the DO concentrations decay in the first 10 kilometers was significant, starting from $7.5 \mathrm{mg} / \mathrm{L}$ and reaching approximately $5.6 \mathrm{mg} / \mathrm{L}$. The remaining DO reductions were small (approximately $0.10 \mathrm{mg} / \mathrm{L}$ ). Ribeirão São José tributary inflow, due to its reduced organic load, produced a significant increase in the Pardo river DO concentrations, to approximately $6.5 \mathrm{mg} / \mathrm{L}$. It is important to note that, even though DO concentrations remained above the environmental quality limit established for class 2 rivers uses, the reduction of DO concentrations may affect the aquatic community, mainly due to the extinction of species more sensitive to oxygen concentrations variations.

Figure 4 shows the DO and BOD concentration profiles for the Pardinho river, which receives raw effluents from Irupi municipality. The BOD concentration peak, related to the final disposal of cited effluent, reaches $13.0 \mathrm{mg} / \mathrm{L}$, substantially higher than the quality standard for rivers class 2 uses $(5.0 \mathrm{mg} / \mathrm{L})$. As a consequence, there is DO consumption, producing, approximately, $6.1 \mathrm{mg} / \mathrm{L}$ minimum concentration.

Figure 5 presents the $\mathrm{DO}$ and $\mathrm{BOD}$ concentration profiles for the tributary Ribeirão Perdição, considering the effluents releases produced by Santíssima Trindade and Nossa Senhora das Graças, rural villages that belong to Iúna municipality. DO and BOD concentrations did not change significantly, as these settlements present small populations. In addition, it is important to note that the standards set for DO and BOD for class 2 rivers uses have been met along the entire length of the Ribeirão Perdição tributary.

\section{Minimum effluent treatment efficiencies}

Table 2 summarizes the treatment efficiencies generated for all effluent disposal points in the Pardo river basin, estimated by using the water quality model and the different optimization models considered (optimization models 1 and 2, according to the section Models Optimization).
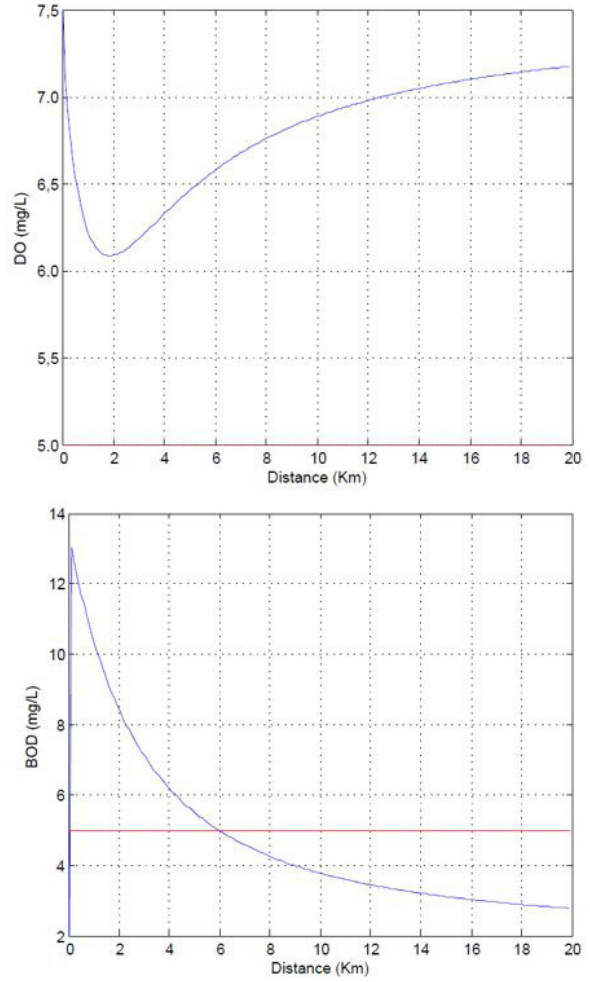

Figure 4. DO and BOD concentration profiles for the Pardinho river.
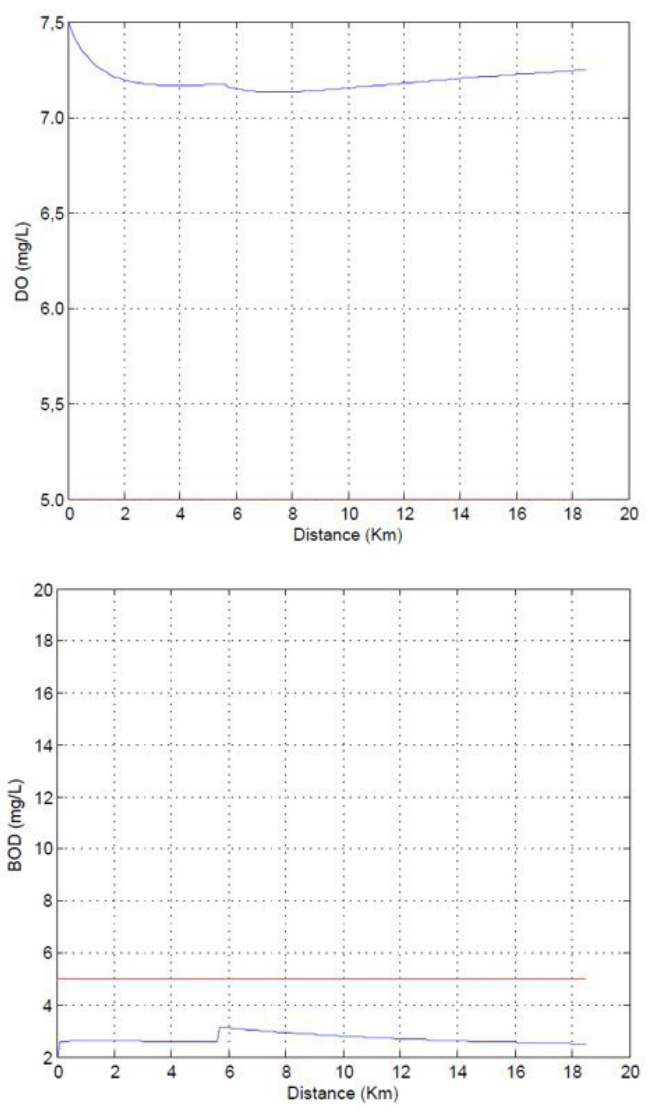

Figure 5. DO and BOD concentration profiles for the Ribeirão Perdição tributary. 
Table 2. Minimum sewage treatment efficiencies estimated by the optimization model applied to the Pardo river basin.

\begin{tabular}{|c|c|c|c|c|c|c|c|}
\hline \multirow{2}{*}{$\begin{array}{c}\text { Effluent } \\
\text { disposal } \\
\text { condition }\end{array}$} & \multirow[b]{2}{*}{ SOLUTIONS } & \multicolumn{5}{|c|}{ LOCALITY } & \\
\hline & & Ibatiba & Irupi & $\begin{array}{c}\text { Nossa Senhora das } \\
\text { Graças }\end{array}$ & $\begin{array}{c}\text { Santíssima } \\
\text { Trindade }\end{array}$ & Iúna & \\
\hline \multicolumn{7}{|c|}{ Optimization Model 1} & Sum \\
\hline & 1 & 82 & 73 & 0 & 0 & 0 & 155 \\
\hline & 2 & 82 & 74 & 0 & 0 & 0 & 156 \\
\hline \multirow[t]{5}{*}{1} & 3 & 82 & 73 & 0 & 0 & 0 & 155 \\
\hline & 4 & 82 & 73 & 0 & 0 & 0 & 155 \\
\hline & 5 & 82 & 73 & 0 & 0 & 0 & 155 \\
\hline & 1 & 84 & 73 & 71 & 71 & 71 & 370 \\
\hline & 2 & 82 & 73 & 70 & 70 & 70 & 365 \\
\hline \multirow[t]{5}{*}{2} & 3 & 83 & 73 & 70 & 70 & 71 & 367 \\
\hline & 4 & 84 & 73 & 71 & 70 & 71 & 368 \\
\hline & 5 & 83 & 73 & 71 & 71 & 71 & 369 \\
\hline & 1 & 82 & 74 & 60 & 61 & 60 & 337 \\
\hline & 2 & 82 & 74 & 61 & 61 & 62 & 340 \\
\hline \multirow[t]{3}{*}{3} & 3 & 82 & 73 & 60 & 60 & 60 & 335 \\
\hline & 4 & 82 & 73 & 60 & 61 & 62 & 338 \\
\hline & 5 & 83 & 73 & 61 & 60 & 62 & 339 \\
\hline \multicolumn{8}{|c|}{ Optimization Model 2} \\
\hline & 1 & 95 & 73 & $(4) *$ & (2)* & 94 & 264 \\
\hline & 2 & 95 & 73 & $(4)^{*}$ & $(2)^{*}$ & 95 & 269 \\
\hline \multirow[t]{3}{*}{1} & 3 & 95 & 73 & (4)* & $(2)^{*}$ & 95 & 269 \\
\hline & 4 & 94 & 73 & (4)* & $(2)^{*}$ & 95 & 269 \\
\hline & 5 & 95 & 73 & $(8)^{*}$ & $(3)^{*}$ & 95 & 274 \\
\hline
\end{tabular}

* Notes: Treatment efficiencies generated by the optimization model. Von Sperling (2007) suggested that for secondary sewage treatment systems, the minimum efficiency of BOD removal should be approximately $25 \%$.

According to Von Sperling (2007), secondary sewage treatment systems present a minimum BOD removal efficiency corresponding to approximately $25 \%$. From this perspective, in the subsequent table, all estimated efficiencies presenting values less than $25 \%$ were presented in parentheses, next to the symbol " $<25$ ". In Table 2, the highlights represent the efficiencies, per sewage disposal point, that led to the lowest sum of efficiencies in the Pardo river basin.

Figure 6 shows the DO and BOD concentration profiles for the Pardo river after the incorporation of the effluent treatment efficiencies estimated by using the optimization model 1, assuming the final disposal of raw effluents (condition 1 of final effluents disposal). In this case, according to Table 2, Ibatiba and Irupi municipalities sewage treatment efficiencies $82 \%$ and $73 \%$, respectively, were assumed. For the other urban areas (Iúna city and Santíssima Trindade and Nossa Senhora das Graças districts), release of raw sewage was considered.

At the confluence of the São José tributary with the Pardo river a significant dilution of domestic sewage was observed, since the cited tributary does not receive any sewage discharge. Pardo River BOD concentrations reached maximum values $4.9 \mathrm{mg} / \mathrm{L}$ (due to Ibatiba sewage final disposal) and $3.3 \mathrm{mg} / \mathrm{L}$ (function of Iúna sewage final disposal) immediately after the sewage disposal points. As a consequence of the self-purification process, the BOD concentration was reduced to $2.3 \mathrm{mg} / \mathrm{L}$.

For the DO profile, Pardo river showed little variations, with concentration reduction to a minimum approximately $7.0 \mathrm{mg} / \mathrm{L}$, due to the discharge of domestic effluent from Ibatiba district. The influx of the São José tributary, as a function of dilution processes, produced an increase in the Pardo river DO concentration to approximately $7.3 \mathrm{mg} / \mathrm{L}$.
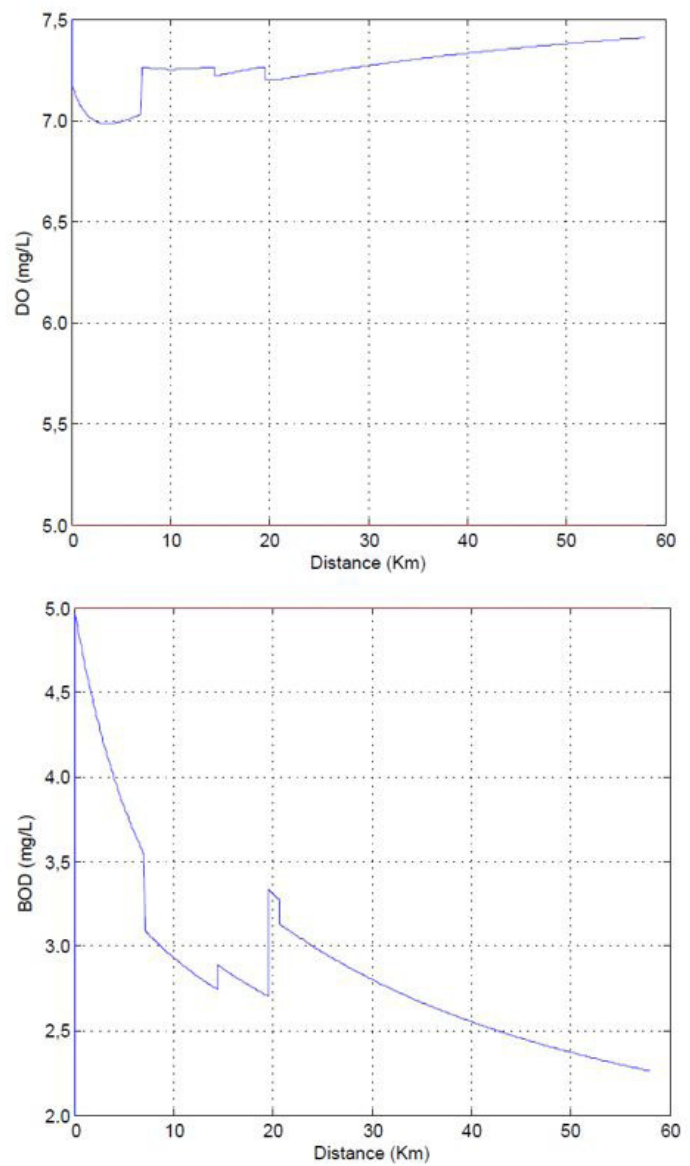

Figure 6. DO and BOD concentration profiles for Pardo river - results associated with optimization model 1, effluent disposal condition 1. 
The Pardinho river DO and BOD concentration profiles are presented in Figure 7. The BOD peak concentration, related to the cited effluent final disposal, reached $4.85 \mathrm{mg} / \mathrm{L}$, concentration close to the maximum limit established by CONAMA Resolution $357 / 2005$. In the DO profile, estimated variations were not relevant.

Figure 8 shows the DO and BOD concentration profiles for the Ribeirão Perdição tributary, considering the releases of effluents produced by Santíssima Trindade and Nossa Senhora das Graças, rural villages that belong to Iúna municipality. DO and BOD concentrations did not change significantly, since these villages present small numbers of inhabitants. In addition, it is important to note that the standards set for DO and BOD for class 2 rivers use have been met along the entire length of the Ribeirão Perdição tributary, even assuming the prospect of raw sewage final disposal.

Graphs similar to those presented in Figures 6, 7 and 8 were produced for the other final effluents disposal conditions and optimization models employed.
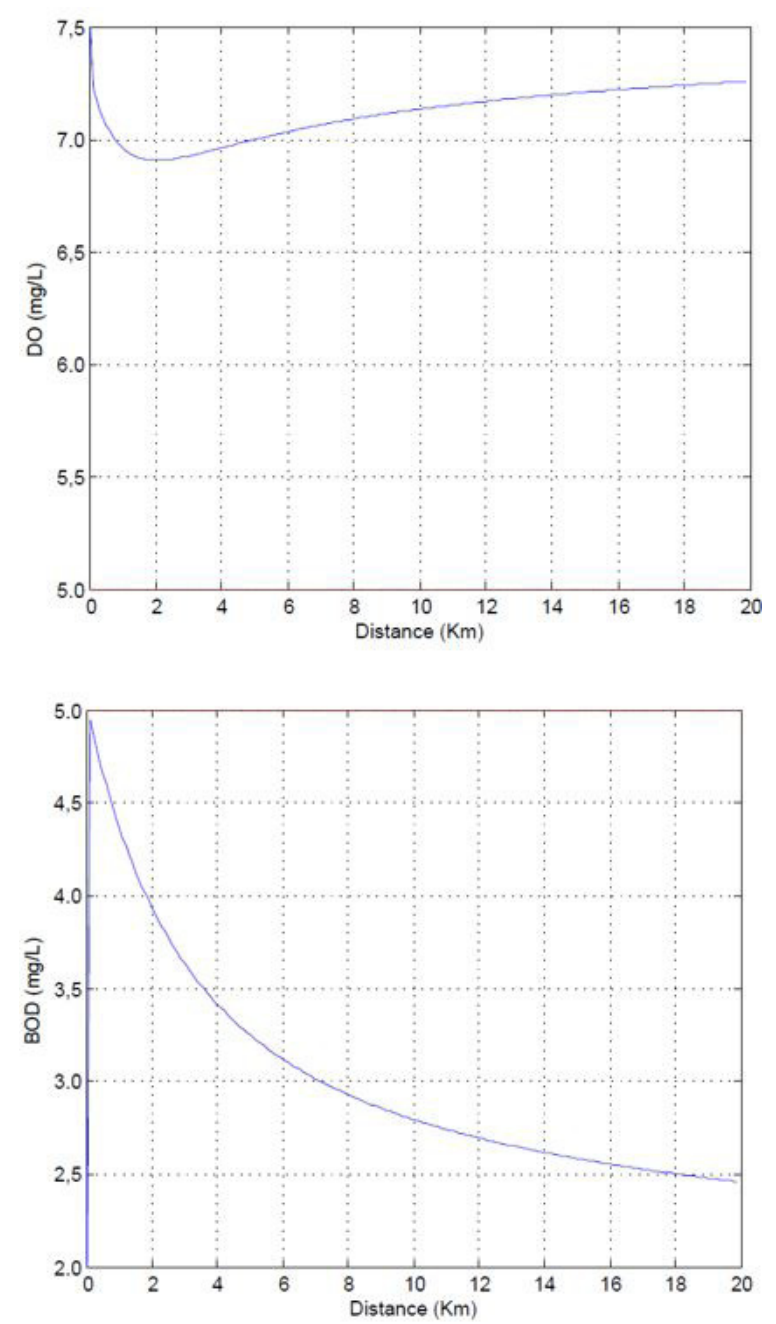

Figure 7. DO and BOD concentration profiles for the Pardinho river - results associated to optimization model 1, effluent disposal condition 1.

\section{Effluent treatment systems}

Table 3 shows the pre-selected effluent treatment systems for the perspective in which minimum BOD removal efficiency is the only technical criterion, considering the final disposal and increasing CPL values, being considered Condition 1 effluents disposal and efficiencies estimated with the aid of optimization model 2. Tables similar to Table 3 were produced for the other scenarios and effluents disposal conditions.

Table 4 presents, by disposal point, scenario and treatment condition, the sewage treatment system that presented the lowest CPL. Table 5, in turn, shows referred treatment systems CPL values and total CPL for the Pardo river watershed.

When Pardo river basin watercourses self-purification capacities were ignored (restriction imposed by conditions 2 and 3, optimization model 1), the slow infiltration systems resulted as sewage treatment alternatives for different localities, considering a simulation scenario in which efficiency was the only technical criterion (scenario 1).
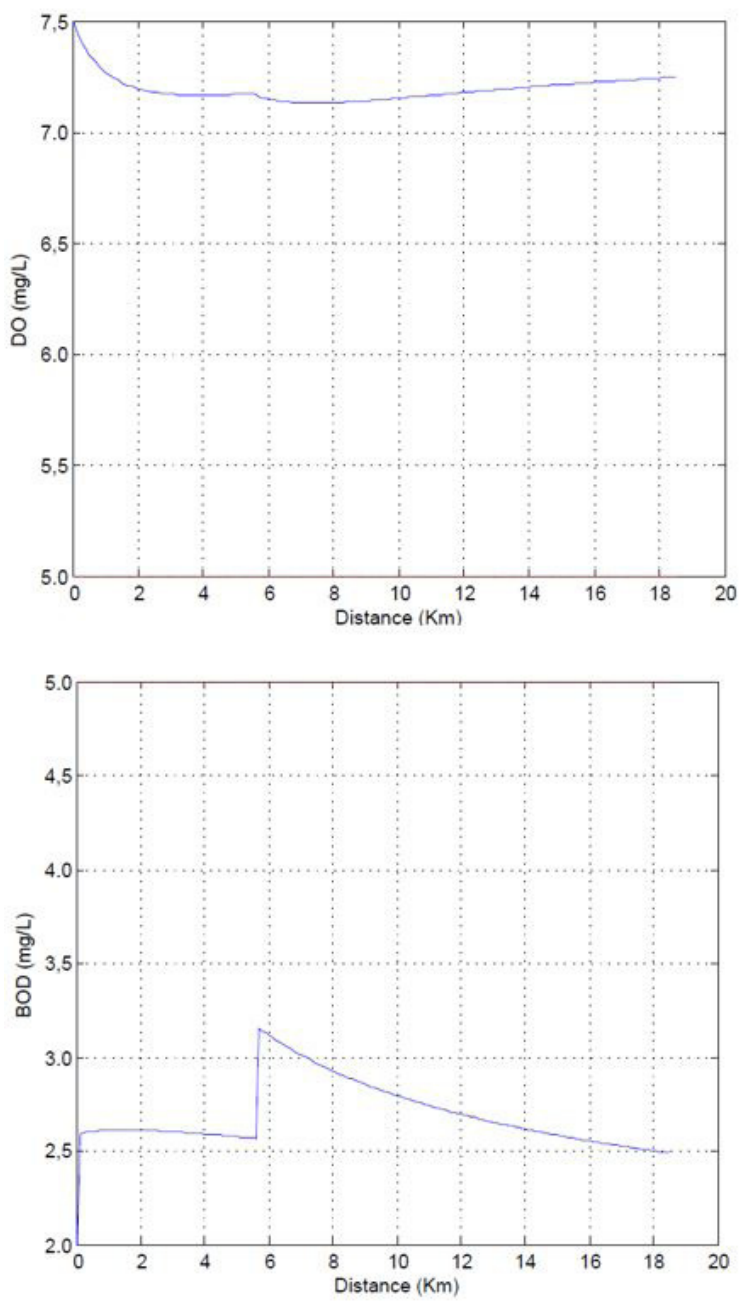

Figure 8. DO and BOD concentration profiles for the Ribeirão Perdição tributary - results associated with optimization model 1, effluent disposal condition 1. 


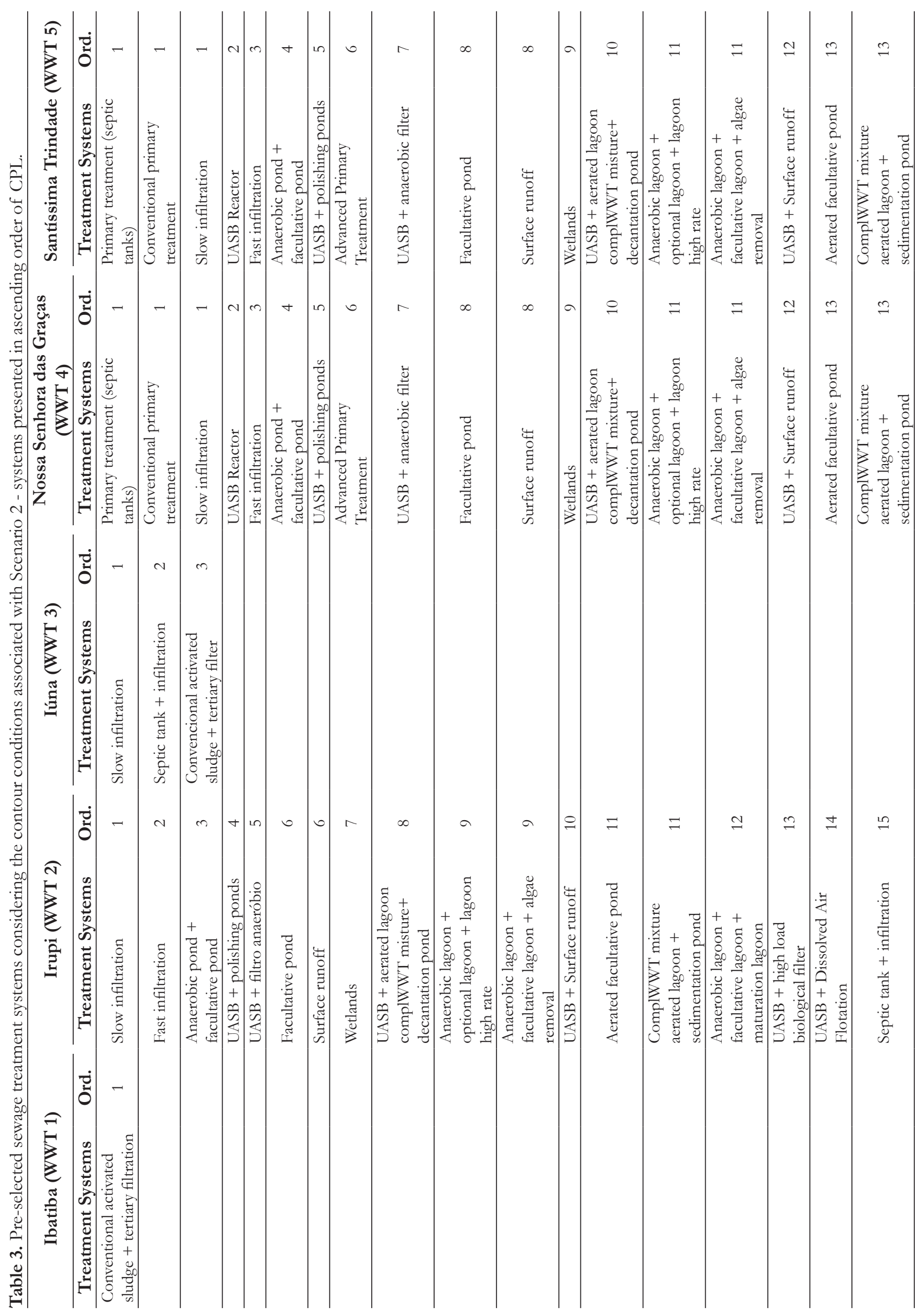




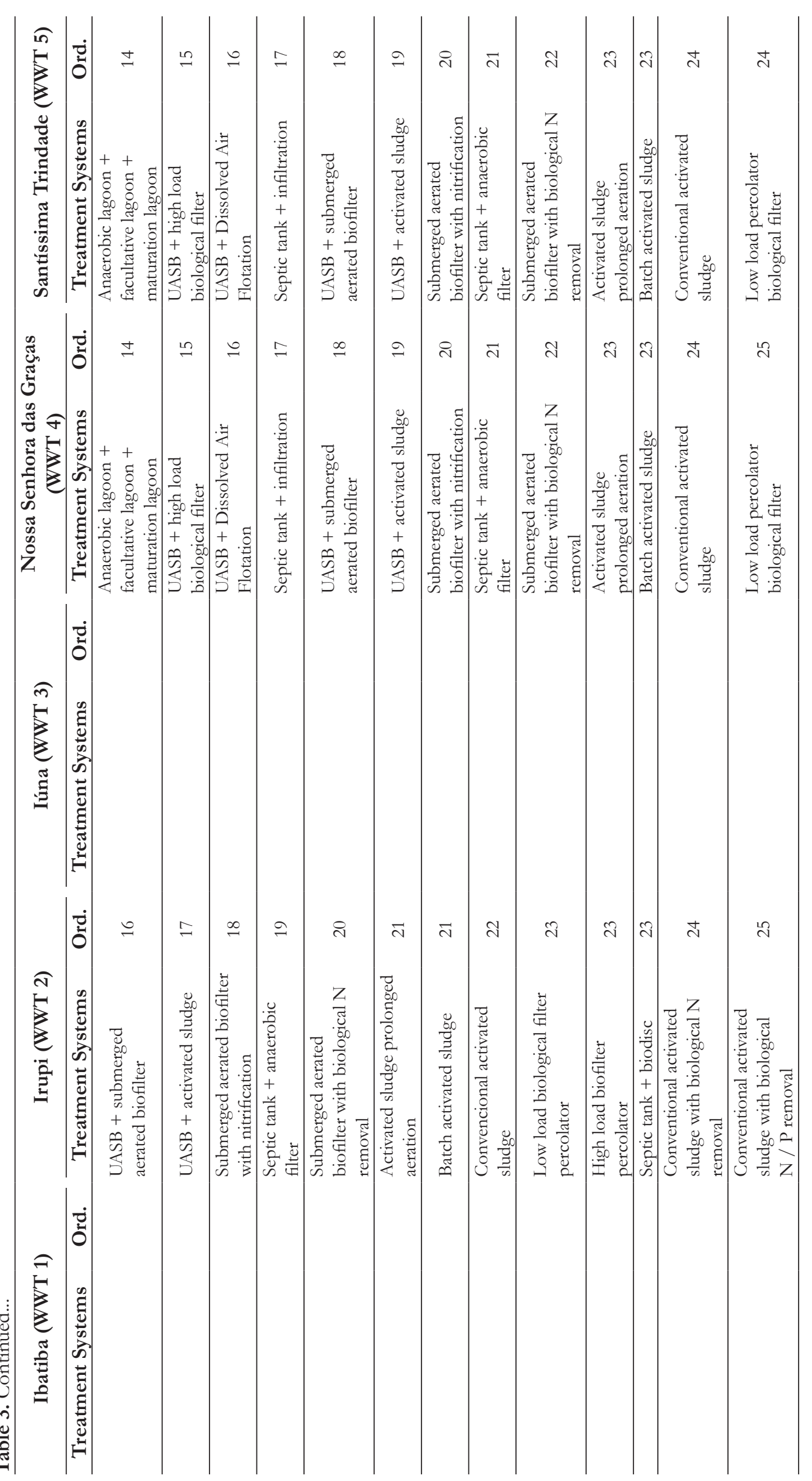


Table 4. Pre-selected sewage treatment alternatives according to simulation panoramas.

\begin{tabular}{|c|c|c|c|c|}
\hline \multirow{3}{*}{ SCENARIOS } & \multicolumn{4}{|c|}{ TREATMENT CONDITIONS } \\
\hline & \multicolumn{2}{|c|}{ Condition 1} & \multirow{2}{*}{$\begin{array}{c}\text { Condition } 2 \\
\text { Optimization Model } 1\end{array}$} & \multirow{2}{*}{$\begin{array}{c}\text { Condition } 3 \\
\text { Optimization Model } 1\end{array}$} \\
\hline & Optimization Model 1 & Optimization Model 2 & & \\
\hline \multirow{5}{*}{ Scenario 1} & WWT 1 - Slow infiltration & $\begin{array}{l}\text { WWT } 1 \text { - Conventional } \\
\text { activated sludge }+ \text { tertiary } \\
\text { filtration }\end{array}$ & WWT 1 - Slow infiltration & WWT 1 - Slow infiltration \\
\hline & WW' 2 - Slow infiltration & WWT 2 - Slow infiltration & WWT 2 - Slow infiltration & WWT 2 - Slow infiltration \\
\hline & - & WWT 3 - Slow infiltration & WWT 3 - Slow infiltration & WWT 3 - Slow infiltration \\
\hline & - & $\begin{array}{l}\text { WWT } 4 \text { - Primary treatment } \\
\text { (septic tanks), Conventional } \\
\text { primary treatment }\end{array}$ & WWT 4 - Slow infiltration & WWT 4 - Slow infiltration \\
\hline & - & $\begin{array}{l}\text { WWT } 5 \text { - Primary treatment } \\
\text { (septic tanks), Conventional } \\
\text { primary treatment }\end{array}$ & WWT 5 - Slow infiltration & WWT 5 - Slow infiltration \\
\hline \multirow{5}{*}{ Scenario 2} & $\begin{array}{l}\text { WWT } 1 \text { - UASB + Polishing } \\
\text { ponds }\end{array}$ & Not selected & $\begin{array}{l}\text { WWT } 1 \text { - UASB + Polishing } \\
\text { ponds; }\end{array}$ & $\begin{array}{l}\text { WWT } 1 \text { - UASB + Polishing } \\
\text { ponds }\end{array}$ \\
\hline & $\begin{array}{c}\text { WWT } 2 \text { - Anaerobic pond }+ \\
\text { Facultative pond }\end{array}$ & $\begin{array}{c}\text { WWT } 2 \text { - Anaerobic pond }+ \\
\text { Facultative pond }\end{array}$ & $\begin{array}{c}\text { WWT } 2 \text { - Anaerobic pond }+ \\
\text { Facultative pond }\end{array}$ & $\begin{array}{c}\text { WWT } 2 \text { - Anaerobic pond }+ \\
\text { Facultative pond }\end{array}$ \\
\hline & - & Not selected & $\begin{array}{c}\text { WWT } 3 \text { - Anaerobic pond }+ \\
\text { Facultative pond }\end{array}$ & WWT 3 - UASB Reactor \\
\hline & - & $\begin{array}{l}\text { WWT } 4 \text { - Primary treatment } \\
\text { (septic tanks) }\end{array}$ & $\begin{array}{c}\text { WWT } 4 \text { - Primary treatment } \\
\text { (septic tanks), Conventional } \\
\text { primary treatment }\end{array}$ & WWT 4 - UASB Reactor \\
\hline & - & $\begin{array}{l}\text { WWT } 5 \text { - Primary treatment } \\
\text { (septic tanks) }\end{array}$ & $\begin{array}{c}\text { WWT } 5 \text { - Primary treatment } \\
\text { (septic tanks), Conventional } \\
\text { primary treatment }\end{array}$ & WWT 5 - UASB Reactor \\
\hline \multirow{5}{*}{ Scenario 3} & $\begin{array}{l}\text { WWT } 1 \text { - UASB + Polishing } \\
\text { ponds }\end{array}$ & $\begin{array}{l}\text { WWT } 1 \text { - Conventional } \\
\text { activated sludge }+ \text { tertiary } \\
\text { filtration }\end{array}$ & $\begin{array}{l}\text { WWT } 1 \text { - UASB + Polishing } \\
\text { ponds; }\end{array}$ & $\begin{array}{l}\text { WWT } 1 \text { - UASB + Polishing } \\
\text { ponds }\end{array}$ \\
\hline & $\begin{array}{c}\text { WWT } 2 \text { - Anaerobic pond }+ \\
\text { Facultative pond }\end{array}$ & $\begin{array}{c}\text { WWT } 2 \text { - Anaerobic pond }+ \\
\text { Facultative pond }\end{array}$ & $\begin{array}{c}\text { WWT } 2 \text { - Anaerobic pond }+ \\
\text { Facultative pond }\end{array}$ & $\begin{array}{c}\text { WWT } 2 \text { - Anaerobic pond }+ \\
\text { Facultative pond }\end{array}$ \\
\hline & - & $\begin{array}{c}\text { WWT } 3 \text { - Conventional } \\
\text { activated sludge + tertiary } \\
\text { filtration }\end{array}$ & $\begin{array}{c}\text { WWT } 3 \text { - Anaerobic pond+ } \\
\text { Facultative pond }\end{array}$ & WWT 3 - UASB Reactor \\
\hline & - & $\begin{array}{l}\text { WWT } 4 \text { - Primary treatment } \\
\text { (septic tanks), Conventional } \\
\text { primary treatment }\end{array}$ & WWT 4 - Slow infiltration & WWT 4 - Slow infiltration \\
\hline & - & $\begin{array}{l}\text { WWT } 5 \text { - Primary treatment } \\
\text { (septic tanks), Conventional } \\
\text { primary treatment }\end{array}$ & WWT 5 - Slow infiltration & WWT 5 - Slow infiltration \\
\hline
\end{tabular}

When the boundary conditions associated to scenario 2 (use of systems that do not demand electrical energy and non-admissibility of soil treatment and final disposal systems) were assumed, the combination of UASB reactors and polishing ponds composed the system that presented lower CPL for Ibatiba municipality (most populous municipality located in the basin).

For Irupi and Iúna municipalities, the lower CPL were associated to the combination of anaerobic pond and facultative pond (Irupi and Iúna municipalities, effluent treatment condition 2 and Irupi, effluent treatment condition 3) or UASB reactors (Iúna municipality, effluent treatment condition 3).

For Nossa Senhora das Graças and Santíssima Trindade villages, when the maximum effluent BOD could not exceed $120 \mathrm{mg} / \mathrm{L}$ (condition 2), the lower cost systems corresponded to the conventional primary treatment or the use of septic tanks. When $60 \%$ minimum BOD removal efficiency was required (condition 3) the system presenting the lowest CPL for the referred villages was the UASB reactor.

For the third simulation scenario (scenario in which treatment systems that demand energy would not be accepted for the villages, although soil disposal constituted an alternative), slow infiltration was presented as an alternative of lower CPL for Nossa Senhora das Graças and Santíssima Trindade. For Ibatiba, Irupi and Iúna municipalities, treatment alternatives presenting lower CPL were the same as those suggested for scenario 2, regardless the effluent treatment condition.

Due to the similarity between the suggested treatment systems, the total CPL values for the Pardo river basin for the effluent treatment conditions 2 and 3 were equal or very close, regardless of the scenario chosen for the systems selection.

When the final disposal of raw effluents (condition 1), in which sewage could be assimilated by the watercourses self-purification 
Table 5. CPL values por pre-selected sewage treatment alternatives according to simulation panoramas.

\begin{tabular}{|c|c|c|c|c|}
\hline \multirow{3}{*}{ SCENARIOS } & \multicolumn{4}{|c|}{ TREATMENT CONDITIONS } \\
\hline & \multicolumn{2}{|c|}{ Condition 1} & \multirow{2}{*}{$\frac{\text { Condition } 2}{\text { Optimization Model } 1}$} & \multirow{2}{*}{$\begin{array}{c}\text { Condition } 3 \\
\text { Optimization Model } 1\end{array}$} \\
\hline & Optimization Model 1 & Optimization Model 2 & & \\
\hline \multirow{7}{*}{ Scenario 1} & WWT 1 - R\$1,861,512.99 & WWT 1 - R\$7,977,912.81 & WWT 1 - R $\$ 1,861,512.99$ & WWT 1 - R\$1,861,512.99 \\
\hline & WWT 2 - R\$ 769,289.46 & WW'T 2 - R\$769,289.46 & WWT 2 - R\$769,289.46 & WWT 2 - R\$ 769,289.46 \\
\hline & - & WWT 3 - R\$1,233,304.30 & WWT 3 - R $\$ 1,233,304.30$ & WWT 3 - R\$1,233,304.30 \\
\hline & - & WW'T 4 - R\$159,064.83 & WWT 4 - R\$159,064.83 & WWT 4 - R\$159,064.83 \\
\hline & - & WWT 5 - R\$180,230.19 & WWT 5 - R\$180,230.19 & WWT 5 - R\$180,230.19 \\
\hline & TOTAL $=\mathbf{R} \$$ & TOTAL $=\mathbf{R} \$$ & TOTAL $=\mathbf{R} \$$ & TOTAL $=\mathbf{R} \$$ \\
\hline & $2,630,802.45$ & $10,319,801.54$ & $4,203,401.77$ & $4,203,401.77$ \\
\hline \multirow{7}{*}{ Scenario 2} & WWT 1 - R\$2,692,545.57 & Not selected & WWT 1 - R\$2,692,545.57 & WWT 1 - R\$2,692,545.57 \\
\hline & WWT 2 - R\$1,025,719.28 & WWT 2 - R\$ 1,025,719.28 & WWT 2 - R\$1,025,719.28 & WWT 2 - R\$1,025,719.28 \\
\hline & - & Not selected & WWT 3 - R\$ 1,644,405.73 & WWT 3 - R\$ 1,262,668.68 \\
\hline & - & WWT 4 - R\$159,064.83 & WWT 4 - R\$159,064.83 & WWT 4 - R\$162,852.09 \\
\hline & - & WW' 5 - R\$180,230.19 & WWT 5 - R\$180,230.19 & WWT 5 - R\$184,521.39 \\
\hline & TOTAL $=\mathbf{R} \$$ & - & TOTAL $=\mathbf{R} \$$ & TOTAL $=\mathbf{R} \$$ \\
\hline & $3,718,264.86$ & & $5,701,965.60$ & $5,328,307.01$ \\
\hline \multirow{7}{*}{ Scenario 3} & WWT 1 - R\$ 2,692,545.57 & WWT 1 - R\$ 7,977,912.81 & WWT 1 - R\$2,692,545.57 & WWT 1 - R\$2,692,545.57 \\
\hline & WWT 2 - R\$ 1,025,719.28 & WWT 2 - R\$ 1,025,719.28 & WWT 2 - R\$1,025,719.28 & WWT 2 - R\$1,025,719.28 \\
\hline & - & WWT 3 - R\$5,285,589.84 & WWT 3 - R\$1,644,405.73 & WWT 3 - R\$1,262,668.68 \\
\hline & - & WWT 4 - R\$159,064.83 & WWT 4 - R\$159,064.83 & WWT 4 - R\$159,064.83 \\
\hline & - & WWT 5 - R\$180,230.19 & WWT 5 - R\$180,230.19 & WWT 5 - R\$180,230.19 \\
\hline & TOTAL $=\mathbf{R} \$$ & TOTAL $=\mathbf{R} \$$ & TOTAL $=\mathbf{R} \$$ & TOTAL $=\mathbf{R} \$$ \\
\hline & $3,718,264.86$ & $14,628,516.95$ & $5,701,965.60$ & $5,320,228.56$ \\
\hline
\end{tabular}

capacities, was admitted, treatment systems were only suggested for Ibatiba and Irupi municipalities. The systems with lower CPL were slow infiltration (Ibatiba and Irupi municipalities, scenario 1), UASB associated with polishing ponds (Ibatiba, scenarios 2 and 3) or anaerobic lagoons combined with facultative lagoons (Irupi, scenarios 2 and 3). In addition, an increase of more than 50\% (fifty percent) was observed in the total sewage treatment costs for the watershed, when the final disposal of effluents condition 1 was replaced by effluent treatment conditions 2 and 3, regardless of the systems selection criteria combination.

The equity perspective for the treatment systems, established by using optimization model 2 , increased the minimum treatment levels for Ibatiba and Iúna municipalities (according to minimum efficiencies presented in Table 2). Hence, there were demanded more sophisticated treatment alternatives for these municipalities - systems produced by combination of conventional activated sludge and tertiary filtration. As a consequence, the Pardo River watershed total CPL values were increased by approximately four times. It is important to note that optimization model 2 was used only for the condition by which raw effluents final disposal was admitted (condition 1).

The simulation scenario that did not admit the use of mechanized systems and the use of soil treatment and final disposal systems (scenario 2), did not allow identification of sewage treatment systems for Ibatiba and Iúna municipalities. According to Table 2, the estimated treatment efficiencies for Ibatiba and Iúna were $95 \%$ and $94 \%$, respectively. From the analysis of the sewage treatment alternatives considered in this study, none of the non-mechanized systems present average BOD removal efficiency compatible with the treatment efficiencies demanded for Ibatiba and Iúna municipalities.

\section{CONCLUSIONS}

The present study main conclusions can be summarized as follows:

- Water quality model combined with the optimization technique allowed the appropriation of the minimum BOD removal efficiencies for the different Pardo river basin effluent disposal points. When not considered the equity perspective between treatment systems (optimization model 1), efficiencies ranged from zero to $82 \%$ (assuming the possibility of raw sewage final disposal), between $70 \%$ and $82 \%$ (when established maximum $120 \mathrm{mg} / \mathrm{L} \mathrm{BOD} \mathrm{for}$ treated effluent) and between $60 \%$ and $82 \%$ (when imposed minimum treatment efficiency 60\%). The highest sum of efficiencies in the Pardo river basin was obtained for the effluent treatment condition that imposed maximum $120 \mathrm{mg} / \mathrm{L}$ BOD value for treated effluent;

- Equity perspective between treatment systems, incorporated by optimization model 2 , required higher BOD removal efficiencies for Ibatiba and Iúna municipalities (95\% and $94 \%$, respectively). In addition, the incorporation of equity consideration increased the sum of efficiencies within the basin, when considering the efficiencies estimated by the optimization model 1 for the same final effluents disposal condition;

- When equity between treatment systems (optimization model 1) was not considered, the selected treatment systems ranged from slow infiltration (a system often indicated when minimum treatment efficiency is the only technical selection criterion), and associations between reactors UASB 
and polishing lagoons, and between anaerobic lagoons and facultative lagoons;

- The incorporation of the equity perspective among treatment systems, due to the increase of the minimum levels of treatment for Ibatiba and Iúna municipalities, indicated for these localities the combination of conventional activated sludge with tertiary filtration processes. As a consequence, the CPL values derived from the systems selected from the incorporation of equity were substantially higher, approximately four times greater than the estimated without consideration of equity perspective between systems. For the selection scenario where mechanized systems were not allowed, the incorporation of equity perspective did not allow selection of treatment systems for Ibatiba and Iúna municipalities.

\section{REFERENCES}

ANDRADE, L. N.; MAURI, G. R.; MENDONÇA, A. S. F. A general multiobjective model and a simulated annealing algorithm for waste-load allocation. Journal of Water Resources Planning and Management, v. 139, n. 3, p. 339-344, 2013. http://dx.doi.org/10.1061/ (ASCE)WR.1943-5452.0000257.

ARAS, E.; TOGAN, V.; BERKUN, M. River water quality management model using genetic algorithm. Enviromental Fluidic Mechanical, v. 7, n. 5, p. 439-450, 2007. http://dx.doi.org/10.1007/ s10652-007-9037-4.

BRASIL. Resolução CONAMA no 357, de 17 de março de 2005. Dispõe sobre a classificação dos corpos de água e diretrizes ambientais para o seu enquadramento, bem como estabelece as condições e padrões de lançamento de efluentes, e dá outras providências. Diário Oficial [da] República Federativa do Brasil, Brasília, DF, 17 mar. 2005.

BRASIL. Resolução CONAMA no 430, de 13 de maio de 2011. Dispõe sobre as condições e padrões de lançamento de efluentes, complementa e altera a Resolução no 357, de 17 de março de 2005, do Conselho Nacional do Meio Ambiente-CONAMA. Diário Oficial [da] República Federativa do Brasil, Brasília, DF, 13 maio 2011.

BURN, D. H.; YULIANTI, J. S. Waste-load allocation using genetic algorithms. Journal of Water Resources Planning and Management, v. 127, n. 2, p. 121-129, 2001. http://dx.doi.org/10.1061/(ASCE)07339496(2001)127:2(121).

CALMON, A. P. S.; SOUZA, J. C. S.; REIS, J. A. T.; MENDONÇA, A. S. F. Uso combinado de curvas de permanência de qualidade e modelagem da autodepuração como ferramenta para suporte ao processo de enquadramento de cursos d'água superficiais. Revista Brasileira de Recursos Hidricos, v. 21, n. 1, p. 118-133, 2016. http:/ / dx.doi.org/10.21168/rbrh.v21n1.p118-133.

CHO, J. H.; LEE, J. H. Multi-objective waste load allocation model for optimizing waste load abatement and inequality among waste dischargers. Water, Air, and Soil Pollution, v. 225, n. 3, p. 1-17, 2014. http://dx.doi.org/10.1007/s11270-014-1892-2.

CHO, J. H.; SEOK SUNG, K.; RYONG HA, S. A river water quality management model for optimising regional wastewater treatment using a genetic algorithm. Journal of Environmental Management, v. 73, n. 3, p. 229-242, 2004. PMid:15474740. http:// dx.doi.org/10.1016/j.jenvman.2004.07.004.

EPA - UNITED STATES ENVIROMMENTAL PROTECTION AGENCY. Rates, constants and kinetics formulations in surface water quality modeling. Athens: EPA, 1985.

HIRSCHFELD, H. Engenharia econômica e análise de custos. São Paulo: Atlas, 2012.

HOLLAND, J. H. Adaptation in natural and artificial systems. Michigan: University of Michigan Press, 1975.

HOLLAND, J. H.; GOLDBERG, D. E. Genetic algorithms in search, optimization, and machine learning. Massachusetts: Addison-Wesley, 1989.

IEMA - INSTITUTO ESTADUAL DE MEIO AMBIENTE E RECURSOS HÍDRICOS. Cariacica, 2015. Disponível em: <http://www.meioambiente.es.gov.br/>. Acesso em: 20 fev. 2015.

JORDÃO, E. P.; PESSOA, C. A. Tratamento de esgotos domésticos. Rio de Janeiro: ABES, 2005.

LACERDA, E. G. M.; CARVALHO, A. C. P. L. F. Introdução aos algoritmos genéticos. In: GALVÃO, C. O.; VALENÇA, M. J. S. (Ed.). Sistemas inteligentes: aplicações a recursos hidricos e ciências ambientais. Porto Alegre: UFRGS, 1999. p. 99-150.

MARSH, M. T.; SCHILLING, D. A. Equity measurement in facility location analysis: a review and framework. European Journal of Operational Research, v. 74, n. 1, p. 1-17, 1994. http://dx.doi. org/10.1016/0377-2217(94)90200-3.

MICHALEWICZ, Z. Genetic algorithms + Data structures = Evolution programs. Berlin: Springer Berlin Heidelberg, 1994.

MULLIGAN, G. F. Equality measures and facility location. Regional Science, v. 70, n. 4, p. 345-365, 1991. http://dx.doi.org/10.1007/ BF01434593.

NICKLOW, J. W.; KAINI, P.; ARTITA, K. Optimizing structural best management practices using SWAT and genetic algorithm to improve water quality goals. Journal of Water Resources Planning and Management, v. 26, n. 7, p. 1827-1845, 2012. http://dx.doi. org/10.1007/s11269-012-9989-0.

PALIWAL, R.; SHARMA, P.; KANSAL, A. Water quality modelling of the river Yamuna (India) using QUAL2E-UNCAS. Journal of Environmental Management, v. 83, n. 2, p. 131-144, 2007. PMid:16697517. http://dx.doi.org/10.1016/j.jenvman.2006.02.003. 
PARK, S. S.; LEE, Y. S. A water quality modeling study of the Nakdong River, Korea. Ecological Modelling, v. 152, n. 1, p. 65-75, 2002. http://dx.doi.org/10.1016/S0304-3800(01)00489-6.

POPEL, H. J. Aeration and gas transfer. Delft: Delft University of Technology, 1979. 169 p.

REIS, J. A. T.; VALORY, J. P. L.; MENDONÇA, A. S. F. Seleção de eficiências de tratamento de esgotos a partir da manutenção de equidade entre sistemas de tratamento: uma abordagem para o gerenciamento de bacias hidrográficas. Revista Brasileira de Recursos Hídricos, v. 20, n. 4, p. 862-871, 2015. http:/ /dx.doi.org/10.21168/ rbrh.v20n4.p862-871.

SALLA, M. R.; PEREIRA, C. E.; ALAMY FILHO, J. E.; PAULA, L. M.; PINHEIRO, A. M. Estudo da autodepuração do Rio Jordão, localizado na bacia hidrográfica do Rio Dourados. Revista Engenharia Sanitária e Ambiental, v. 18, n. 2, p. 105-114, 2013. http://dx.doi. org/10.1590/S1413-41522013000200002.

SANTORO, M. C. Modelos de otimização para dWWTrminação de eficiências de sistemas de tratamento de efluentes domésticos no âmbito de uma bacia hidrográfica. 2016. 128 f. Dissertação (Mestrado em Engenharia Ambiental) - Universidade Federal do Espírito Santo, Vitória, 2016.

TCHOBANOGLOUS, G.; BURTON, F. L. Wastewater engineering: treatment and reuse. New York: McGraw-Hill, 1991.

TEODORO, A.; IDE, C. N.; RIBEIRO, M. C.; BROCH, S. A. O.; SILVA, J. B. Implementação do conceito Capacidade de Diluição de Efluentes no modelo de qualidade da água QUAL-UFMG: estudo de caso no Rio Taquarizinho (MS). Engenharia Sanitária e Ambiental, v. 18, n. 3, p. 275-288, 2013. http://dx.doi.org/10.1590/ S1413-41522013000300010.

THOMANN, R. V.; MUELLER, J. A. Principles of surface water quality modeling and control. New York: Harper \& Row, 1987.

USP - UNIVERSIDADE DE SÃO PAULO. Núcleo de Pesquisa em Informações Urbanas. Esgotamento sanitário: URBAGUA: limites técnicos e econômicos de alternativas de tratamento de esgoto. São Paulo: Sistema de Apoio à Decisão SAD URBAGUA, 2004. Relatório.

VALORY, J. P. L. Aplicação combinada de método de otimizaçãa e modelo de qualidade de água na dwwtrminação de eficiências de sistemas de tratamento de efluentes domésticos: uma abordagem para gerenciamento de bacias bidrográficas. 2013. 90 f. Dissertação (Mestrado em Engenharia Ambiental) - Universidade Federal do Espírito Santo, Vitória, 2013.
VALORY, J. L.; REIS, J. A. T.; MENDONÇA, A. S. F. Combining genetic algorithms with a water quality model to dwwtrmine efficiencies of sewage treatment systems in watersheds. Journal of Environmental Engineering, 2015. http://dx.doi.org/10.1061/ (ASCE)EE.1943-7870.0001048.

VON SPERLING, M. Principios do tratamento biológico de águas residuárias: introdução à qualidade das águas e ao tratamento de esgotos. Belo Horizonte: DESA/UFMG, 2005.

VON SPERLING, M. Princípios do tratamento biológico de águas residuárias: estudos e modelagem da qualidade da água de rios. Belo Horizonte: DESA/UFMG, 2007.

VON SPERLING, M.; VON SPERLING, E. Challenges for bathing in rivers in terms of compliance with coliform standards. Case study in a large urbanized basin (das Velhas River, Brazil). Water Science and Technology, v. 67, n. 11, p. 2534-2542, 2013. PMid:23752386. http://dx.doi.org/10.2166/wst.2013.145.

ZHANG, R.; QIAN, X.; LI, H.; YUAN, X.; YE, R. Selection of optimal river water quality improvement programs using QUAL2K: a case study of Taihu Lake Basin, China. The Science of the Total Environment, v. 431, p. 278-285, 2012. PMid:22687438. http:// dx.doi.org/10.1016/j.scitotenv.2012.05.063.

ZHU, Y. P.; ZHANG, H. P.; CHEN, L.; ZHAO, J. F. Influence of the South-North Water Diversion Project and the mitigation projects on the water quality of Han River. The Science of the Total Environment, v. 406, n. 1-2, p. 57-68, 2008. PMid:18799199. http:// dx.doi.org/10.1016/j.scitotenv.2008.08.008.

\section{Authors contributions}

Lucas Luiz Dall'Orto Fantin: water quality simulation, determination of treatment efficiencies, economic analysis, analysis and interpretation of results, drafting of manuscript and critical revision.

José Antonio Tosta dos Reis: Analysis and interpretation of results, drafting of manuscript and critical revision.

Antonio Sérgio Ferreira Mendonça: Analysis and interpretation of results, drafting of manuscript and critical revision. 